\title{
（8）美浜地区農業集落排水事業の概要について
}

\author{
一土㙵被覆型接触晶析脱りン法一
}

滋賀県びわ町 土地改良課長 橋本 公佑

\section{I ．地区の概要}

びわ町は, 昭和 31 年に 2 村が合併してできた町で, 滋賀県の東北部に位置し, 琵琶湖中央部に突き出た三 角州地帯です．標高 $87 \mathrm{~m}$, 起伏が少なく, 主要河川が 東西海貫流しており, 南北 $5.35 \mathrm{~km}$, 東西 $11.5 \mathrm{~km}$, 総面 積 $17.23 \mathrm{~km}$, 人口 8,200 人の純農村地帯である. 又, 美浜地区は，町の西部に位置し，姉川に設けた平担な 地域で, 琵琶湖岸に接している.

びわ町では, 昭和 45 年に, 全町農業振興地域の指定 を受け, 同じく都市計画では全町市街化調整区域の指 定を受けている.

昭和46年度より県営圃場整備事業に着手, 続いて団 体営圃場整備事業を実施し, 全町圃場整備事業を完了, 昭和50年度に, 農村総合整備モデル事業の採択を受け, 生産, 生活基盤の整備を図ってきた。

美浜地区については, 一部, 内水面漁業の専業漁家 があるが, 町内各集落と同様, 農家の程んどが第 2 種 兼業農家である。乙のため混住化が進み, 生活様式の 多様化, 高度化により, 今まで家の周囲や畑江穴を掘 り地下浸透による処理を行ってきたが，使用水量の増 加と長期間の使用による目詰まりにより，トブ化し， 悪臭, 蚊, 䗉等の発生を招き, 地下水質も悪化するな よ゙して来たため集落内の河川や，農業用排水路に直接 放流するようになったため, 下流でポンプ掲水に頼っ ている当地区の水田では, 農業経営上, 深刻な問題之 なっている.

てのため, 町では, 農村集落の特性に適合した污水 処理方式を確立し, 生活環境の整備, 農業用水の水質 保全を図るため昭和56年度から農村基盤総合整備事業 （昭和58年度から農業集落排水事業）に取り組み，本 年度までに, 4 地区の採択を受け, 又, 当美浜地区に ついては, 本年 4 月 1 日より供用を開始, 良好な成績 を上げている。

以下，本施設の計画，実施について紹介する.

\section{II . 事業計画}

\section{1 ）地区の設定}

本地区は，琵琶湖に最も近接し標高も低く，集落内 はすとより，上流からの集落排水等が流入するため, 用水保全上緊急な整備が必要であった。旧来から 3 集 落が一体となった伝統的な生活圈域を構成しており， 農業用水の管理, 日常生活の連帯性, レクリエーショ ン等の活動が共同で運営されており, 集落排水処理に おいても, 共同で実施するてとが地元の要求となって 打り, 湖辺 3 集落（八木浜, 大浜, 中浜）を美浜地区 として設定した。

\section{2 ）処理方針と処理方式の決定}

水質污濁の主原因は, 生活雑排水にあり処理の対象 は, し尿及び生活雑排水とし, 雨水は除外した。

処理方式の選定には，農村の特性を考慮し，琵琶湖 富栄養化防止条例に規定されている上乗数値をクリア 一するものとし, 処理能力に優れ, 余剩污泥の発生が 少なく，建設費が安価でしかす冬期寒冷下にあっても， 性能が低下しないもの. 又, 二次公害の発生がなく, 窒素, リンの除去に高度な技術を要せず，性能に優れ， 維持管理が容易で薬品等が安く, しかも, 污泥の発生 が少なく，農地還元が可能なものとした。

\section{3 ）下水管の設定及び処理ブロック}

管路は, 本地区が琵琶湖湖岸に位置するため, 自然 勾配は少ないができるだけ自然流下方式として管路及 び処理ブロック等を比較検討したとてろ, 下水管は比 較的勾配が少なくてすむ硬質塩ビ卵形管 $(200 \phi)$ と し，河川等を越える場合は低圧圧送とし，ポンプ所 （4 力所）を設置した。

処理ブロックは, 維持管理, その他を考慮し， 1 ブ ロックとし, 処理場は地区の中心の字界にある農道 (片側 $50 \mathrm{~m} \times 30 \mathrm{~m}$ の水田のみの利用) 下に決定した。

\section{4 ) 計画の諸元}

(1)計画人口及び処理対象水

計画人口 870 人, 218 戸 ( 4 人 $/ 1$ 戸) 


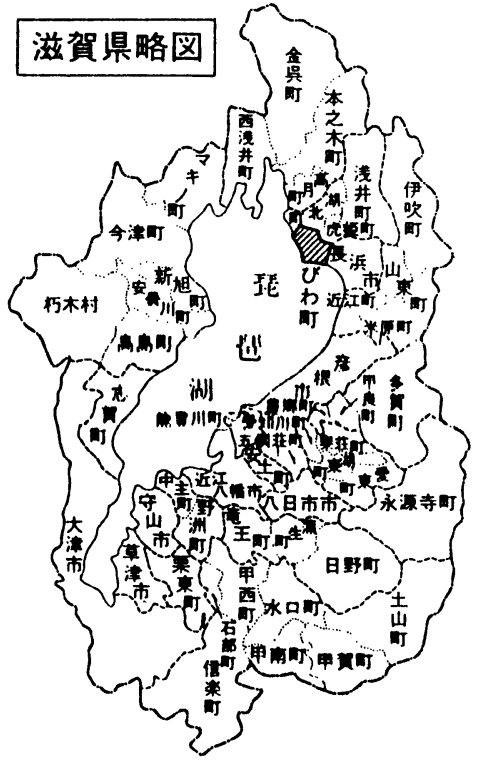

図-1 美浜地区位置図

処理対象水 生活排水 (し尿 + 雑排水)

(2)計画污水量

\section{日平均污水量 $270 \ell /$ 人 \\ 日最大污水量 $330 \ell /$ 日}

処理水量（日最大） $289.1 \mathrm{~m}^{3} /$ 日

(3)計画水質及び処理目標水質, 除去率（表 1 ） (4)総事業費

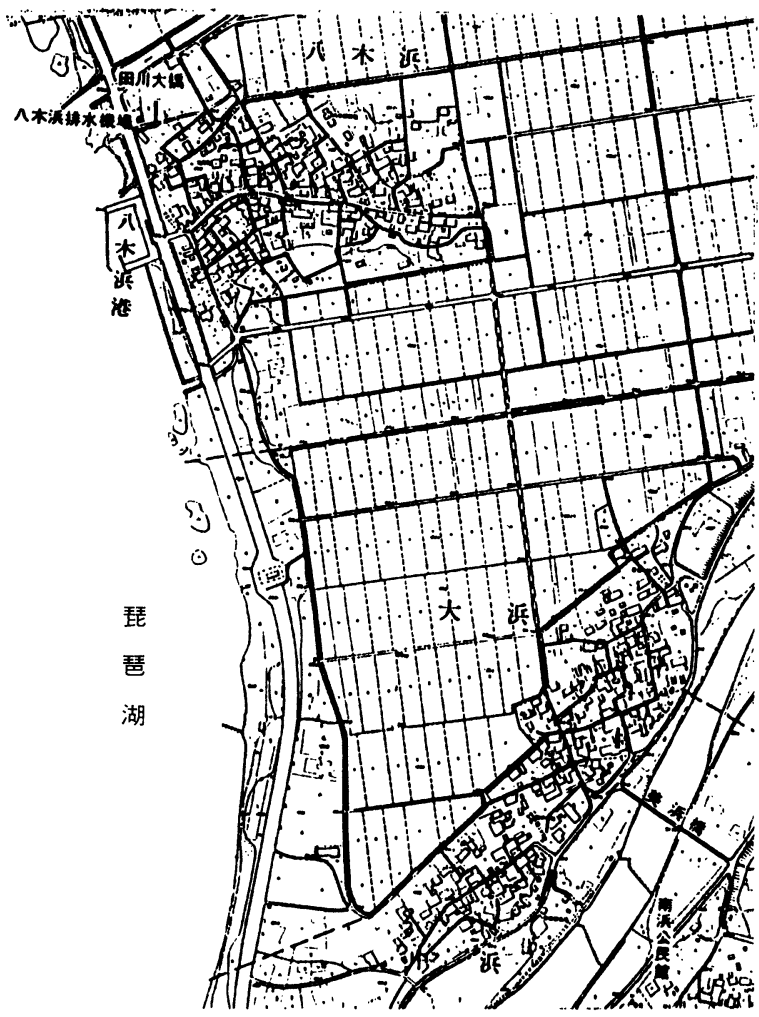

処理施設工事費 1 力所 174,300 千円 管路施設工事費

延長 $5,868.1 \mathrm{~m}$ ポンプ所 4 力所

$\begin{array}{cr}\text { 測量試験費 } & 14,500 \text { 千円 } \\ \text { 工事雑費 } & 13,700 \text { 千円 } \\ \text { 合 計 } & 420,000 \text { 千円 }\end{array}$

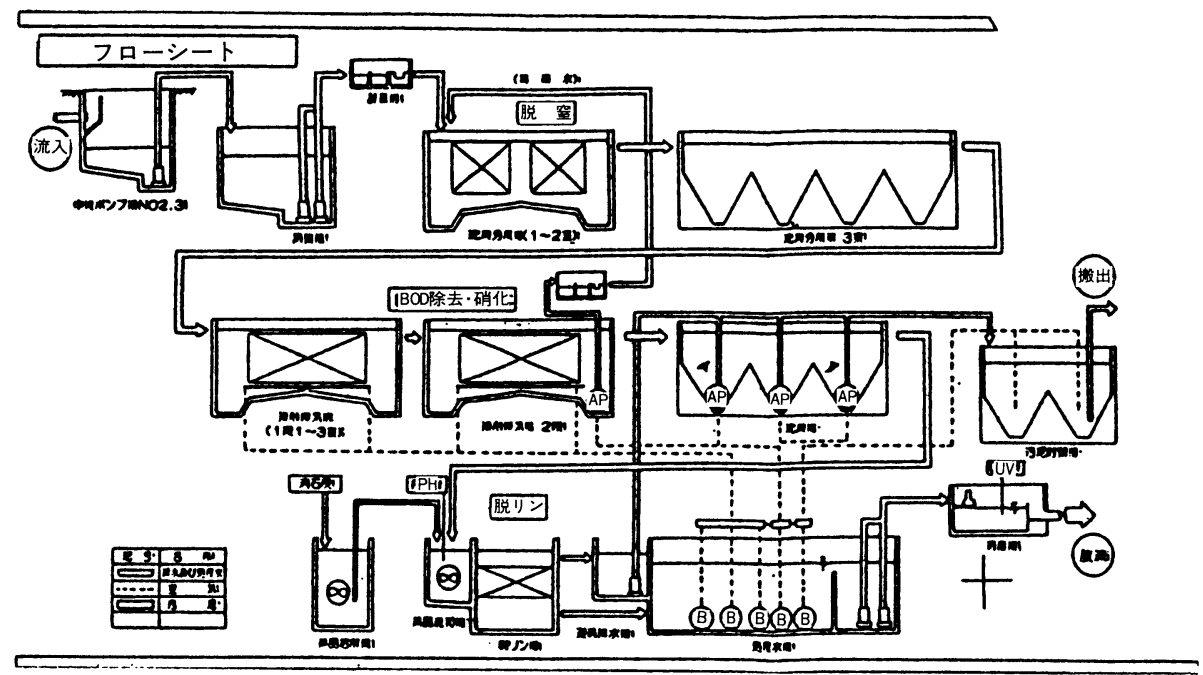

図-2 フローシート 


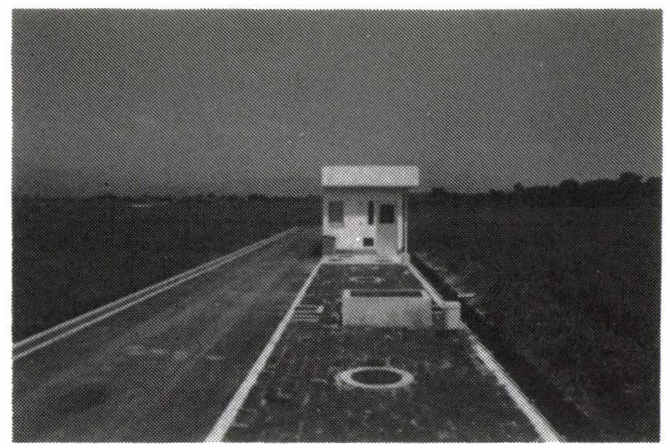

写真 1 美浜地区処理場

\section{III ．計画時の留意点}

本地区は, 湖岸に位置する集落で排水は直接琵琶湖 に流入するため, 污水が河川等に放流されて流下中に 自然浄化を受けて負荷が低められた状況で流入する場 合に比べて, 湖水に対する污濁影響が大きい. 地区内 には漁業を営む漁家む多く水質悪化は漁家の生産にも 影響しており, 琵琶湖富栄養化の原因である窒素, リ ンを含む物質の除去が経済的, 効率的に行われる土壌 被覆型接触ばっき法（長水路型）上循環法を組み合せ, 脱リン性能にすぐれ, 維持管理が容易でかつ使用薬品 が少なく安価で, 污泥の発生がなく, 農地還元が出来 るものとして, 晶析脱リンを採用した.

\section{1 ）脱窒の方法}

循環法

この方法は, 接触ばっ気槽（沪材バイオス）から処 理水を沈殿分離槽へ返送し, 嫌気性状態を利用し, 循 環水中の $\mathrm{NO}_{2}-\mathrm{N}, \mathrm{NO}_{3}-\mathrm{N}$ を脱窒菌の作用によ って還元し, 窒素ガスとして除去する方法であり, 連 続ばっ気運転が可能であり, 建設費が安価である。

\section{2 ) 晶析脱リン法}

処理水中に含まれているリン（リン酸イオン $\mathrm{PO}_{4}^{3^{-}}$) はカルシウムイオン $\mathrm{Ca}^{2}+$ 及び水酸イオン $\mathrm{OH}^{-}$と反 応し, ヒドロキシアバタイト $\mathrm{Ca}^{5}\left(\mathrm{PO}^{4}\right)_{3} \mathrm{OH}$ とな

表 1 計画水質及び処理目標水質（除去率）

\begin{tabular}{|c|c|c|c|c|}
\hline 項 & 目 & 流入 水 & 放流水 & 除去率 \\
\hline B O D & $\mathrm{mg} / \ell$ & 191 & 20 & $90 \%$ \\
\hline S S & & 183 & 70 & 62 \\
\hline COD & & 90 & 20 & 78 \\
\hline $\mathrm{T}-\mathrm{N}$ & & 40 & 20 & 50 \\
\hline $\mathrm{T}-\mathrm{P}$ & & 5.5 & 1 & 82 \\
\hline
\end{tabular}

り，てのヒドロキシアバタイトを晶析材（骨炭）の表 面に連続的結晶させます. 処理槽の中には, 支持層 （拳大の石〜砂）を入れ晶析材を充媜し上部より処理 水を通すことにより, 濾過の役目と共に処理水中のリ ンを除く方法です. このため污泥として排水すること むなく晶析材の再生の必要むない. 晶析材がリンと結 晶して増量してきた場合は, リン酸肥料として農地に 還元できる. 目詰り防止のため 1 日 1 回逆洗している が, 薬品としては, 水酸化カルシウム水溶液 $1 \% （ \mathrm{pH}$ 調整のため）が必要なだけで維持管理屯容易である.

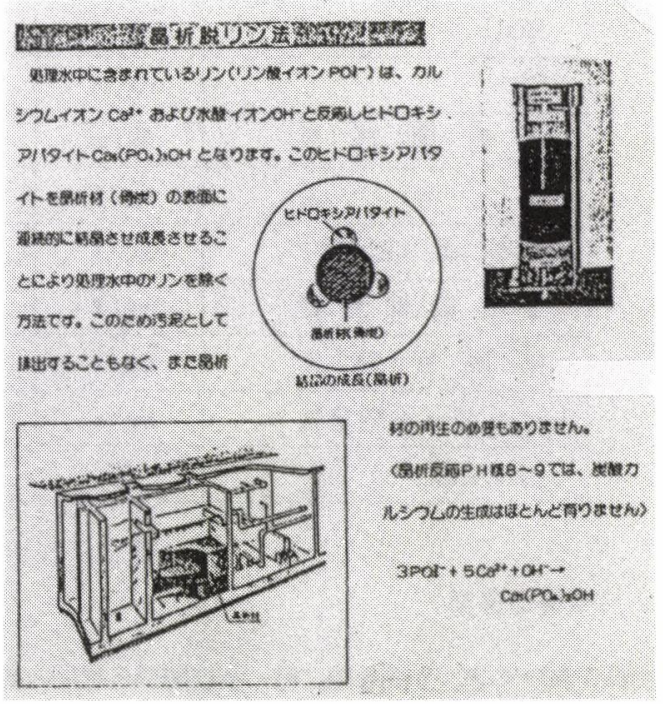

図-3 晶折脱リン法

\section{IV. 維持管理}

\section{1) 管理主体}

恒久的施設の適正な維持管理をめざして, 町が管理 主体となり，技術面は町職員がし尿浄化槽管理士の資 格をとり, 管理し, その他については, 美浜地区農業 集落排水事業維持管理組合が行っている. 使用料は当 分の間, 月額 1 戸当り 2,500 円とした。

\section{2 ) 污泥処理, 水質検査}

発生污泥は, 地力の増進を図るため, 農地へ還元で きる様に, 他の 3 地区の污泥と合せてコンポスト化を 計画している. しかし本地区が本年 4 月 1 日からの供 用で現在約 80 戸が利用し, まだ污泥の発生も少なく, 当面は広域衛生プラントでの処分を協議している.

水質検查は, 毎月実施しているが良好な水質で, そ の結果 (60年 8 月末) は次の上扣りである. 
表 2 水 質検 查 表

美浜地区農業集落家庭排水処理施設維持管理組合長 殿

依頼年月日：昭和60年 8 月26日

分析方法：J I SK0 102 「工場排水試験方法」による

昭和60年 9 月 4 日

三菱樹脂㑣長浜工場環境分析室 濃度計量証明事業登録 滋賀県 第13号

環境計量士

登録番号第環13 号 笹 田憲 治

\begin{tabular}{|c|c|c|c|c|c|c|}
\hline 項 目 試 料 & 単位 & 原 水 & 処理 水 & 脱リン前 & 測 定 & 方 法 \\
\hline $\mathrm{pH}$ & - & 7.1 & 8.0 & 7. 8 & 規格 & 12.1 \\
\hline COD & $\mathrm{mg} / \ell$ & 52 & 3.0 & & 規格 & 17 \\
\hline $\mathrm{BOD}$ & $\mathrm{mg} / \ell$ & 170 & 1.6 & & 規格 & 21 \\
\hline SS & $\mathrm{mg} / \ell$ & 60 & $<1$ & 4 & 規格 & 14.1 \\
\hline 大腸 菌 群 数 & 個 /m $\ell$ & & 不検出 & 6000 & 規格 & 72.3 \\
\hline 全 $\quad り \quad h$ & $\mathrm{mg} / \ell$ & 2.4 & 0.15 & 1.7 & 規格 & 46.3 \\
\hline 全 窒 素 （総和法） & $\mathrm{mg} / \mathrm{l}$ & 42.1 & 6.2 & & 規格 & \\
\hline 亜硝酸性窒素 & $\mathrm{mg} / \ell$ & 0.09 & 0.11 & & 規格 & 43.1 \\
\hline 硝 酸 性 窒 素 & $\mathrm{mg} / \ell$ & $<0.5$ & 6.1 & & 規格 & 44.1 \\
\hline ケルダール態窒素 & $\mathrm{mg} / \ell$ & 42 & $<0.5$ & & 規格 & 45.3 \\
\hline pHの温度 & ${ }^{\circ} \mathrm{C}$ & 28.7 & 28.8 & 28.1 & 規格 & - \\
\hline
\end{tabular}

\section{V. 今後の展望}

町においては, 今後む国, 県, 及び関係各機関の御 指導のあとに, 農業集落排水事業に積極的に取り組み, 生活環境基盤の整備, 農業用用排水及び湖沼等の水質 保全に万全をきたすと共に，恵まれた自然環境の中で
快適な文化生活ができるよう, 環境に調和した事業計 画の樹立, 住民参加による事業推進, 将来に希望の持 てる活力に満ちた町づくりには，農業集落排水事業の 果す役割は, 絶大なあのであり, 今後, ますますの発 展を祈念するむのであります. 